\title{
En omstridt Grundtvig-salme og dens forstadier
}

\author{
Af Thorkild Borup Fensen
}

I. O Christelighed!

Du skiænker vort Hjerte hvad Verden ei veed, Hvad svagt vi kun skimte, mens Øiet er blaat, Det lever dog i os, det føle vi godt;

Mit Land, siger Herren, er Himmel og Jord, Hvor Kiærlighed boer!

2. Lyksalige Lodd, At leve hvor Døden har mistet sin Brodd, Hvor alt hvad som blegned, opblomstrer paany, Hvor alt hvad der segner, opfarer i Sky, Hvor Kiærlighed voxer som Dagen i Vaar,

Med Roser i Haar!

3. Livsalige Land, Hvor Glasset ei rinder med Graad eller Sand, Hvor Blomsten ei visner, hvor Fuglen ei døer, Hvor Lykken er skinnende klar, men ei skiør, Hvor dyrt ikke kiøbes til Krone paa Baar

De snehvide Haar!

4. O Vidunder-Tro!

Du slaaer over Dybet din gyngende Bro, Som Iisgangen trodser i brusende Strand, Fra Dødninge-Hjem til de Levendes Land, Boe lavere hos os, det huger dig bedst, Du høibaarne Giæst!

5. Letvingede Haab!

Gudbroder, nyfødt iden hellige Daab!

$\mathrm{O}$, laan os den Fjederham, Aandens dig gav, Saa tit vi kan flyve til Landet bag Hav, Hvor Evigheds Soel skinner klart allenstund Paa Saligheds Grund! 
6. O, Kicerlighed selv!

Du rolige Kilde for Kræfternes Elv!

Du fylder med Frelserens gavmilde Ord

Velsignelsens Kalk paa det christne Gudsbord;

O, vær du var Livdrik paa Jorden og bliv

Vort evige Liv!

7. O, Kiærligheds Aand!

Som væver i Sandhed Fuldkommenheds Baand!

$\mathrm{O}$, smelt du vort Hjerte ved Høialtrets Ild,

Og klar du Jordklimpen i Solglandsen mild,

Saa glade vi føle, os skabes i Bryst

De Levendes Lyst!

(S-V, IV, nr. 267)

I en prædiken fra $183^{2}$ hævder Grundtvig kategorisk: 》Naar vore Salmer ej udtrykke den levende Folelse af, at vi allerede ere overgangne fra Døden til Livet, have fundet det evige Liv $i$ Guds Kicerlighed og drukket af hans Saligheds Kalk ... da ere de kun matte og svage.«Udsagnet er et godt udgangspunkt for en forståelse af både tema og stil i salmen »O Christelighed « (fra I853).

Grundtvigs salme, (DS 279), er dels en visionær skildring af menighedens betingelsesløse, hele og udelte lyksalighedstilstand (strofe I-3) dels en (ikke mindre) billedmættet fremstilling af årsagerne dertil, både de af menneskelig natur (Tro og Håb, strofe 4-5) og de af guddommelig natur (Kicerlighed, strofe 6-7). Vejen går i salmen fra umiddelbar virkning til højeste årsag, fra menighedens store kollektiv til treenigheden, Sønnen, Faderen og Helligånden (strofe 57). Selv om der i salmen optræder en lang række af teologiske begreber, især fra Johannesevangeliet og Paulusbrevene (Verden, Daab, Liv, Aand, Ord, Evighed, Salighed, Kilde, Velsignelse, Fuldkommenhed, Tro, Haab, Kærlighed), og selv om alle passager i salmen i større eller mindre grad bygger på bibelske vendinger, så virker den ikke som en opbyggelig prædiken eller som en tør teologisk indlæring; bibelske og grundtvigske forestillinger indgår i en uopløselig, suggestiv-anskuelig blanding. Hele digtet er båret af en ekstatisk begejstring over oplevelsen af kristenlivets forjættede land her og nu, tillige af forvisningen om, at oplevelsen vil fortsætte ubrudt - bønnen om evighedslivet er uanfægtet (strofe 7 ).

Menighedsfællesskabet er på en iøjnefaldende måde genstand for salmens lovprisning; DS 279 er ikke blot, i overensstemmelse med 
salmens normale funktion, tænkt som en bekendelsesytring af menigheden, men også som en bekendelse til menigheden. For Grundtvig er »det christelige Liv som et Christus-Liv« (Begtrup VIII, s. 436), substantivet i salmens første linje må på god grundtvigsk vis opfattes ganske bogstaveligt, der tales her om kollektivets lighed med Kristus. Grundtvig er overbevist om, at »Det christelige Livs Hemmelighed (jfr. $\mathrm{I}^{2}$ : »Hvad Verden ei veed «) uforanderlig er den, at de Troende ikke leve deres eget men Hans Liv, som er død og opstanden for os« (Begtrup VIII, s. 442).

Efter I825 forkynder Grundtvig bestandig i sine prædikener, at hvor menigheden samles om dåb og nadver, dér er Kristi nærvær. Når håbet i 5. strofe af »O Christelighed « kaldes »Gudbroder, nyfødt i den hellige Daab«, så aktualiseres dermed forestillingen om menneskets og Kristi samtidige opstandelse. »Gudbrødre « kaldes nemlig de, der døbes samtidig. Der kan for hele strofens vedkommende henvises til $\mathrm{I}$. Pet. $\mathrm{I}^{3}$, som Grundtvig rimeligvis også har $\mathrm{i}$ tanken: »Lovet være Gud ... som har genfødt os til et levende Haab ved Jesu Kristi Opstandelse fra de Døde«. - I 5. strofe udtrykkes »den levende Følelse af, at vi allerede ere overgangne fra Døden til Livet«, nemlig i kraft af kirkens dåbssakrament.

I prædikencitatet ovenfor fordredes det også af salmen, at den udtrykker oplevelsen af at have »drukket af hans (Guds) Saligheds Kalk«. Det sker i 6. strofe af »O Christelighed «, hvor nadverens livgivende kraft lovprises (»Velsignelsens Kalk paa det christne Gudsbord «. »Vor Livdrik paa Jorden«). I det hele taget dvæles der ved kirkens ritualer i salmens slutning, sidstestrofens bøn til helligånden rummer sandsynligvis også en nadverallusion (»o, smelt du vort Hjerte ved Høialtrets Ild «).

Nadvervinens virkning sætter Grundtvig ofte i forbindelse med pinsens under, han vender gang på gang tilbage til, at den hellige drik skaber glødende tunger og brændende hjerter. Ilden forårsager både sindets renselse og følelsens ekstase ( $7^{3}$ : »o, smelt du vort Hjerte «). Grundtvig ræsonnerer ikke over Helligåndens væsen, giver ikke nogen historisk redegørelse for pinsens begivenhed eller nogen teologisk forklaring på nadverhandlingen, men digter i billeder om, hvordan Helligånd, pinse og nadver som en samlet kraft virker på mennesket. Der er i salmen en Ewaldsk gudhengiven begejstring over at »Støvet kan bære / Din Rigdom, Din Ære, / Din Godhed, o Fader!« I en Grundtvig-prædiken fra 6. S. e. påske 1823 forbindes alle de fore- 
stillinger, som indgår i slutstrofens første halvdel; historisk begivenhed og kirkelig handling bliver ét ved menneskets gudgivne oplevelse: »Den himmelske Ild, som fra den første Pinsedag efter Herrens Himmelfart haver brændt paa Alteret i Christi Kirke, i de Christnes Hierte, som er indviet til den HelligAands Tempel ... blusser igien, naar Alteret opbygges i Herrens Navn, i en hellig Flamme mod Himlen«.

Grundtvig taler ikke om synd og frelse eller om trøst i sorg og modgang, men om et allerede - permanent! - eksisterende guddommeligt kærlighedsrige (jfr. især strofe 2-3). Hele salmen vil anskueliggøre, at »det evige Liv i Guds Kiærlighed« (jfr. det indledende citat) er en realitet. Kærligheden, alias kristenlivet, er opfattet som en gave fra Gud $\left(\mathbf{I}^{2}, 2^{1}, 6^{3-4}, 7^{5-6}\right)$, den skildres ikke i dogmatiske vendinger som noget eksklusivt, men i en række konkrete symboler som noget naturgroet og som en naturkraft $2^{5-6}, 5^{5-6}, 6^{2}, 7^{4}$ ), den er både en reel tilstand (jfr. f. eks. strofe 3 ) og en stadig tilblivelse (strofe 2: »opblomstrer«, »opfarer«, »vokser«; strofe 6: »du fylder«; strofe 7: »os skabes«).

Det er karakteristisk, at betydningen af nøgleordet »Kiærlighed « ændres undervejs i digtet, Grundtvigs forestillingsverden er ikke statisk, men labil. I de to første strofer $\left(1^{5-6}, 2^{5-6}\right)$ synes $\gg k æ r l i g h e d e n \ll$ at være en egenskab eller en tilstand blandt mange andre, den er nok guddommelig af kvalitet, men ikke enerådende. I de to sidste strofer tales der ikke længere om, men til kærligheden, den giver livet dets indhold og mening. (I Paulusbrevene møder vi forestillingen om Guds kærlighedssamfund med menneskene, de er Guds tempel. »Ved Helligånden udgydes Guds kærlighed $\mathrm{i}$ evangeliet om Jesu død og opstandelse over menigheden«, siger Paulus).

Der er i salmen $\gg \mathrm{O}$ Christelighed « en tematisk stigning fra menighedsliv til himmelsk fuldkommengørelse, fra tro og håb til kærlighed (af Grundtvig selv kaldt den »christelige Trefoldighed «, Begtrup IX, s. 464), men intet episk forløb og ingen mærkbar sproglig intensivering undervejs - den komplicerede billedfylde er karakteristisk for salmen som helhed. »O Christelighed « udtrykker én uforbeholden begejstring, paradiset, »De Levendes Land $\left(4^{4}\right)$, eksisterer nemlig også her og nu som en sindets realitet for mennesker $\left(\mathbf{1}^{3-4}\right)$. Væksten har for den troende allerede afløst dødens vilkår (strofe 2, jfr. I. Kor. I $5^{55}$ : »Død, hvor er din Sejr? Død, hvor er din Brod?《), forgængelighedens og den timelige bekymrings plage er ophævet 
(strofe 3). Med indledningscitatets ord er vi allerede »overgangne fra Døden til Livet«. Jord og himmel er ikke to helt forskellige verdener, men i kvalitativ forstand én tilværelsesform $\left(\mathrm{I}^{5}, 6^{5-6}\right)$. Kærligheden kommer fra Gud $\left(6^{3}\right)$, men den bor og gror hos mennesker $\left(2^{5-6}, 4^{5-6}\right)$, døden og tiden er afløst af væksten og bestandigheden (henholdsvis strofe 2 og 3 ).

Som salmedigter søger Grundtvig det magtmiddel, hvorved guddommen kan gøres nærværende; i sin bestræbelse tyr han til symbolerne, fordi »Billeder og Lignelser ere os aldeles uundværlige, naar Tanken om de himmelske, de aandelige, de usynlige Ting skal være mere end en tom, en magtesløs Skygge« (prædiken, 2. påskedag r824). Denne æstetiske overbevisning er hos Grundtvig et led i en mere omfattende livsanskuelse: »al menneskelig Tale om aandelige Ting ... er mere eller mindre billedlig ... fordi Aanden hos Mennesket kun virker under legemlige Betingelser, fordi Mennesket, med Siæl og Legeme, kun er et Billede af Guddommen« (Toldberg, s. 230 ).

Grundtvigs symbolbrug, og hans ordudfoldelse overhovedet, illustrerer ikke en på forhånd given tankegang, men kalder besværgende en række i sig selv anelsesfulde forestillinger frem. Enkeltpassager i salmen er sammensat af tilsyneladende inkongruente elementer $\left(3^{1-2}\right.$, $6^{2-4}$ : Graad-Sand, Kalk-Ord); de enkelte metaforer er meget frit kombineret, billedrækker af forskellig art kædes sammen $\left(5^{1-2}, 7^{3-4}\right)$. I de komplicerede billedstrukturer indgår begreber fra vidt forskellige kulturkredse, således forenes i 4. og 5. strofe nordisk mytologi med bibelske forestillinger, i 7. strofe ( $\gg$ smelt du vort Hjerte ved Høialtrets Ild«) en gammeltestamentlig skik, brændofferet på alteret, med en nytestamentlig betydning. (Paulus: $\gg$ Den kristne Menighed har intet andet Offeralter end Jesu Kors«. Johs. Åb.: »Røgelse er de hellige Bønner«, »Jeres Legeme er et Tempel for Helligånden«).

Allusionsteknikken udnyttes på mangfoldig og raffineret vis; bag udsagnet i $3^{4}$ (»hvor Lykken er skinnende klar, men ei skiør«) ligger et af Peder Syvs ordsprig: »Lykken er af Glar, hun brister, naar hun skinner klar«. Rimeligvis moddigter Grundtvig samtidig Kingo, der $\mathrm{i} \gg$ Far, Verden, far vel« kalder denne verdens skønhed for »skygger og skinnende glar, bobler og skrattende kar«. De to følgende versinjer $\mathrm{i}$ samme strofe af $\gg \mathrm{O}$ Christelighed $\ll\left(3^{5-6}\right)$ rummer en skjult hentydning til Ordsprogenes Bog ( $\left.16^{31}\right)$, hvor det hedder, at »grå Hår er en dejlig Krone«. Denne passage i salmen om det for- 
jættede land peger i øvrigt mod to forskellige betydningsområder på én gang, både mod dødens ophævelse (»hvor dyrt ikke kiøbes ... paa Baar«) og mod bekymringens og besvaerets ophævelse (»hvor dyrt ikke kiøbes... de snehvide Haar $\ll)$. »Jordklimpen« $\left(7^{4}\right)$ har den bibelske betydning, et forgængeligt menneske (S-V I, s. 282: »Paasken ... giver Jordklimp Himmel-Smag«), men bevarer også den konkrete betydning, en våd og kold jordklump (på marken), som kun solen kan opløse til muld og derved gøre tjenlig til såning.

Udnyttelsen af ordenes flertydighed fører over i ordspillet, glosen »Livdrik « $\left(6^{5}\right)$ får i sammenhængen sin bogstavelige betydning (en drik for hele livet, en drik der fremkalder åndeligt liv), samtidig med at den har sin tidligere gængse betydning (yndlingsdrik). Betydningsglidningen kan iagttages mange steder i digtet; i slutningen af 2. strofe er der et godt eksempel på, hvordan et begreb anskueliggøres ved en sammenligning (»hvor Kiærlighed voxer som Dagen i Vaar«), men derefter sprænger billedets grænse og tiltvinger sig personligt egetliv, kærligheden bliver en smykket kvinde (»med Roser i Haar«).

Strofe to og tre kan betragtes som en række fortættede visioner, billederne yngler uafladeligt. Med god grund hævder Grundtvig: »Jeg vil slet ikke indlade mig paa Forskjellen mellem Poetisk og Prophetisk, men heller, efter Bibelens Exempel, lade begge Begreber sammensmelte«, (Begtrup IV, s. 703). Samtlige udsagn i »O Christelighed « henviser mere eller mindre tydeligt til, eller bygger i større eller mindre grad på, bibelsproget. For Grundtvig er Bibelen den »Billed-Bog som $\mathrm{i}$ faste, ubevægelige Ord aabenbarede, hvorledes man rettelig skulde betragte Herrens Gierninger og slutte fra det Synlige til det Usynlige« (Prædiken, 2. påskedag I 824). Det tematiske nøgleord (kærlighed) og dets anvendelse i salmen henter således sin inspiration fra Det ny Testamente, f. eks. kan der henvises til Johannesevangeliet (»Kærlighed selv er Gud«) og Paulusbrevene (I. Kor, I3: »Kærligheden ophører aldrig ... så bliver da Tro, Haab, Kærlighed ... men størst af dem er Kærligheden«; Rom 5: »Og Håbet gør ikke til Skamme; thi Guds Kærlighed er udgydt i vore Hjerter ved Helligaanden, som blev os givet «; Kol. 3: »Og over alt dette skal I iføre jer Kærligheden, som er Fuldkommenhedens Baand $\ll)$.

»De Levendes Land « $\left(4^{4}\right)$, et betydningsladet udtryk af blandet herkomst, besynges i digtet som Det gamle Testamentes forjættede land (jfr. Johs. $28^{13}$, Ps. $27^{13}$ og $5^{2^{7}}$ ), men også som paradiset på den- 
ne jord $\left(5^{4}\right)$, som den »Lycksalighetens ö« svenskeren Atterbom digter om i et drama fra I820'erne. - Det romantiske fællesgods (lykkedrømmen om Atlantis eller Østerlandet) omtolkes kristeligt af Grundtvig, og på samme måde af $\mathrm{H}$. C. Andersen. I eventyret om »Paradisets Have« taler han om broen, der »førte over Vandet til Lyksalighedens Øe, hvor Paradisets Have blomstrede« (jfr. $4^{1-2}$ ). Selv forestiller Grundtvig sig i ungdomsafhandlingen om »Religion og Liturgi« fra 1806 livet som omgivet af et uoverskueligt bølgende hav og formoder, at der »paa hiin Side Havet maae være et Land med skiønnere Vexter og renere Luft«.

I »Religion og Liturgi« udtaler Grundtvig om salmesangens virkning: »Høit over Jorden maa vi opløftes, og et Glimt af det evige Liv maa svæve forbi vort mod Himlen stirrende Øje.« Et lille halvt århundrede senere sigter Grundtvig stadig mod den ekstatiske løftelse gennem salmen, den er »et fælles ... Udtryk af Herrens Forjæettelser ... og Guds Børns Hiertelag « (Theol. Mdsskr. I828). I de mellemliggende år er der for Grundtvig sket det, at ordet er blevet til guddommens åbenbaring. At digte er nu ikke blot at finde ordenes illusionskraft, men at give udtryk for Guds stadige nærvær blandt menigheden. I S-V, III s. 332, taler Grundtvig opfordrende til Kristenheden: »Skab et apostolisk Tungemaal,/glødende af Guddomsordet«. Dette digteriske udsagn kan læses som Grundtvigs krav til sig selv som salmedigter. -

Læser man Grundtvigs prosa, så bliver man hurtigt klar over, at hans egentlige hjemsted er lyrikken. Grundtvigs talrige teologiske afhandlinger imponerer ved deres idefylde og deres utraditionelle perspektiver, men ikke ved deres klare ræsonnementer. Den intellektuelle præcision er ikke Grundtvigs særkende, det er derimod den ynglende billedrigdom, den associative ytringsrække. Både som prosaist og som lyriker er Grundtvig den forkyndende seer, en overordentlig belæst og alsidigt orienteret sprogbruger. Grundtvig når det geniale som salmedigter og som teologisk skribent, men hans monomane ordoptagethed, hans impulsive verbaludfoldelse, peger mod lyrikken. Den dristige metaforbrug, de glidende ordbetydninger, de mange ordspil, allusioner og bevidste paradokser hos Grundtvig gør ham til en moderne digter.

Tilsyneladende flyder poesien fra Grundtvig med rivende hast, det er dog ikke ensbetydende med, at han er en ukritisk kunstner. 
Grundtvig kan producere overfladiske brugsrimerier (eksemplerne er især at finde blandt de bibelhistoriske viser), men han kan også kritisk arbejde sine tekster om og om igen med en utrættelig iver. Den stadige selvrevision er kendetegnende for Grundtvig. Ved at sammenholde nr. 279 med nr. 649 i DS får vi et indtryk af, hvor nødigt Grundtvig slipper en tekst; her gælder det ikke blot detailændringer, men netop en gennemgribende omarbejdelse.

Revisionen er dog ikke så radikal, som salmebogen giver det udseende af; opr. havde de to salmer en fælles grundstamme, idet samtlige syv strofer $\mathrm{i} \gg \mathrm{O}$ Christelighed « var genkendelige bearbejdelser af et tilsvarende antal strofer $\mathrm{i} \gg \mathrm{O}$ dejlige Land . Salmernes beslægtethed udviskedes ved salmebogens kraftige beskæring af $\gg O$ dejlige Land«, man har stort set udeladt det fælles stof; de oprindelige seksten strofer er blevet til ti (i DS 649). Salmebogens version af »O dejlige Land« er ikke blot en kraftig forkortelse af Grundtvigs egen tekst men også en forvanskning af den, idet man har foretaget en fuldstændig omplacering af stroferne og ydermere indflettet nogle strofer fra en helt tredje Grundtvig-variant af salmen!

Skal man tro salmebogen, hidrører både DS 279 og DS 649 fra året $\mathrm{I} 83_{2}$, men oplysningen er kun rigtig for den enes vedkommende. »O Kristelighed « fremkommer, først i 5. oplag af Grundtvigs egne »Fest-Psalmer « fra 1853, ganske i den skikkelse vi kender fra den nuværende salmebog, hvorimod »O dejlige Land« offentliggøres $\mathrm{i}$ I 832 under overskriften »De levendes Land « i L. C. Hagens antologi »Historiske Psalmer og Riim til Børne-Lærdom«. Hos Hagen angives det, at »O deilige Land « er skrevet over melodien til Kingos »Far, Verden, far vel«. Det falder da også i øjnene, når man blot kigger på den typografiske opstilling, at Grundtvig overtager Kingos strofeform med de fire langlinjer og de to indrammende kortlinjer. Afhængigheden stikker imidlertid dybere end som så.

Grundtvigs salmedigtning kan og må i stort omfang betragtes i lyset af dens forhold til barokpoetens salmer. Ustandselig bearbejder Grundtvig de Kingo'ske kirkesange eller bruger dem som udgangspunkt for egne salmer. Grundtvig beundrer Kingo som kunstner og moddigter ham som kristen forkynder.

Både $\mathrm{i} \gg \mathrm{O}$ dejlige Land« og i »O Kristelighed« følger Grundtvig i kunstnerisk henseende baroktidens salmist et langt stykke på vej. Hos begge salmedigtere begynder enkeltstroferne med en begrebsanråbelse og fortsætter med en udfoldelse af begrebets indhold i mas- 
sivt ynglende, suggererende billedrækker, ofte formet som parallelle udsagn. (Kingo: »Det er jo kun Skygger og skinnende Glar/Det er jo kun Bobler og skrattende Kar / Det er jo kun Ise-Skrog / Skarn og Fortred«. Grundtvig: »hvor Glasset ei rinder/hvor Blomsten ei visner... hvor Fuglen ei dør, / hvor Lykken er .../ hvor dyrt ikke kiøbes...«)

Begge digtere taler profetisk om det forjættede lands evige lyksalighed (jfr. DS $525^{10}$, DS $279^{2-3}$ ), men hvor Kingo opstiller paradislykken som et modstykke til jordelivets usle bedrag, dér ophæver Grundtvig det skarpe skel mellem jord og himmel, legeme og ånd. Verbalt er der ikke langt fra Kingos til Grundtvigs ekstatiske beskrivelse af foreningen med Guddommen (»Far, Verden, far vel «, strofe I4, 》O Kristelighed «, strofe 7), men omstændighederne, hvorunder foreningen sker, er totalt forskellige. Hos Kingo sker det $\gg I$ Abrahams Skiød《 hos Grundtvig i »Templet af Muld« (DS 649 ${ }^{8}$ ).

Hos Kingo tjener kødet syndens lov, mennesket kan kun befri sig for $\gg$ Forfængelighed « ved en kraftig viljesakt $\left(\mathrm{I}^{5}\right.$ : »Jeg river mig løs«). Først når mennesket ganske vender verden ryggen, kan foreningen med Gud realiseres, hvilket er ensbetydende med tilværelsen i »yst« $\left(I 5^{1}\right)$ og »Kiærlighed « $\left(I 4^{4-5}\right)$. Hos Grundtvig findes »kærligheden « på jorden såvel som i himlen (strofe $\mathrm{I}^{5-6}$ ) og »lyst《 indgives os i levende live af Helligånden (strofe $7^{5-6}$ ), Gud tager bolig i mennesket.

Menneskets tilværelse er hos Grundtvig (i »O Kristelighed«) en harmonisk vækst, der sluttelig når fuldkommenheden (strofe $7^{2}$ ). Der er en gennemført tematisk stigning i digtet. Hos Kingo er tilværelsen et enten - eller: Det dennesidige liv er idel forfængelighed, det hinsidige er idel lyksalighed - hvis mennesket vel at mærke ved omvendelse her og nu bestræber sig på at tage bolig hos Gud. Kingos digt demonstrerer kompositionelt sit tema ved at være tvedelt. I »O Kristelighed « lever mennesket i samfund med Gud og næsten (strofe I), døden overvindes ved troen og ved sakramenterne (strofe $4-6$ ); i »Far, Verden, far vel« er den enkeltes fuldstændige afdøen fra verden forudsætningen for et evigt liv (strofe 9). Grundtvig digter om menighedslivet, Kingo om det enkelte menneskes liv; Kingos digt er i modsætning til Grundtvigs ikke knyttet til kirkens handlinger.

Fra Grundtvigs hånd eksisterer der tre versioner af salmen om »De Levendes Land«, hvoraf de to er omtalt, henholdsvis »O dejlige Land« fra 1832 og $\gg O$ Kristelighed« fra 1853 . Den forste af dem 
(»Jeg kjender et Land«), der stammer fra I824, ligger idemæssigt og kunstnerisk tottest på Kingos digt.

Som en reminiscens af pilgrimstemaet $\mathrm{i} \gg \mathrm{Far}$, Verden, far vel findes i 1824 denne besyngelse af paradislandet: »Livsalige Land. Hvor det ikkun fattes, som smertede her. / Hvert Menneske søger med Langsel i Bryst / Din smilende Kyst!« Her spores endnu en tydelig forskel $\mathrm{i}$ indstillingen til det dennesidige og det hinsidige. I »Jeg kjender et Land « gives der altså indirekte udtryk for, at mennesket kan være »Keed af Verdenog kier ad Himmelen«. - Denne Kingoske formel har totalt mistet sin gyldighed for Grundtvig i 1853 .

Et iøjnefaldende træk ved både $1824-$ og 1832 -versionen af Grundtvigs salme, til forskel fra 1853 -versionen, er, at de indledningsvis $\mathrm{i}$ en række strofer skildrer menneskers illusoriske og falske forsøg på selv at skabe sig et jordisk paradis (jfr. DS $649^{2-5}$ ). Som hos Kingo fungerer den systematiske afvisning af en selvtillidsfuld lykkesøgende tilværelsesform som den negative baggrund for skildringen af den sande måde at leve på (jfr. DS 6496 ff): I 824og tildels i 832-versionen har bevaret baroksalmens symmetriske opbygning, dens aksefaste og pompøse anlæg.

Som optakten (»Jeg kjender et Land«) lader formode, er den tidligst skrevne version et udpræget jeg-digt; i 1824 slutter Grundtvig af med den strofe (»O Christelighed«), hvormed han i 1853 begynder; først ved strofegrupperingen i den sidste af de tre versioner betones det, at menighedslivet er udgangspunkt for og årsag til oplevelsen af »de Levendes Land«.

Ud fra en astetisk betragtning er den tredje og sidste omarbejdelse af digtet (fra I 853) måske ikke den mest interessante eller værdifulde; »O Christelighed « er imidlertid den af versionerne, der i størst udstrækning honorerer salmegenrens specielle krav.

De $i$ artiklen benyttede forkortelser:

Begtrup: N. F. S. Grundtvigs Udvalgte Skrifter ved Holger Begtrup, I-X.

$D S:$ Den danske Salmebog ( 1953 ).

$S-V$ : Sang-Værket.

Theol. Mdsskr.: Theologisk Maanedsskrift (Grundtvig anmelder her i i 3. bd., I828, 》Psalmer og aandelige Sange af Thomas Kingo《, udgivet af P. A. Fenger).

Toldberg: se nedenfor. 
Af den litteratur, som artiklen bygger på, skal næunes:

Peter Skautrup: De levendes land (Grundtvig-Studier, 1956).

Kaj Thaning: Grundtvigs Møde med Irenæus (Grundtvig-Studier, 1953).

Helge Toldberg: Grundtvigs Symbolverden (1950).

Kursiveringerne $\mathbf{i}$ det foregående er mine. 